\title{
TANTANGAN DALAM PERAWATAN ORAL LICHEN PLANUS PADA PASIEN DIABETES MELITUS (LAPORAN KASUS)
}

\section{Ravina Naomi Tarigan* Titiek Setyawati**}

\author{
* Peserta Program Pendidikan Dokter Gigi Spesialis, Departemen Ilmu Penyakit Mulut, Fakultas \\ Kedokteran Gigi, Universitas Indonesia \\ ** Staf Akademik Departemen Ilmu Penyakit Mulut, Fakultas Kedokteran Gigi, \\ Universitas IndonesiaJl. Salemba Raya No.4, Jakarta Pusat. Telp. (021) 2303257
}

\begin{abstract}
Oral lichen planus (OLP) is a chronic inflammatory condition that effects oral mucous membranes with a variety of clinical presentations including reticular, atrophic, plaque and ulcerative lesions. Corticosteroid is one of the effective therapy for OLP in reducing the sign and symptoms of this disease, but this therapy have a serious side effect, therefore to administering one must consider the patient's systemic condition. We reported a case of OLP in 52 years old female patient who has no history of diabetes mellitus and unknown glucose level. Management of this patient included application of corticosteroid swish, topical $0.05 \%$ clobetasol propionate and $0,1 \%$ triamcinolone acetonide, antimycotics, improvement the oral hygiene status and referral to internal medicine specialist. The next treatments plan challenging because unstable blood glucose level which in turn effects the drug choice and teeth extraction plan. We concluded that the treatment of OLP requires a complete assessment of medical status and lab studies specially on the first visit so the drug selection with corticosteroid therapy and the treatment planning of predisposing factor are effective in reducing the sign and symptoms of OLP with minimum systemic side effect.
\end{abstract}

Key Words: treatment, oral lichen planus, diabetes mellitus

\section{Pendahuluan}

Oral lichen planus (OLP) merupakan penyakit mukokutaneus kronis yang bersifat autoimun yang biasanya melibatkan mukosa rongga mulut, ${ }^{1,2}$ yaitu berupa inflamasi kronis yang mengenai epitel berlapis skuamosa. ${ }^{3}$ OLP merupakan penyakit akibat rusaknya sel basal dengan latar belakang kondisi imunologis yang penyebabnya tidak diketahui ${ }^{1,4-6}$. Diduga merupakan keadaan yang abnormal dari respon imun sel $\mathrm{T}^{7,4}$ pada epitelium basal yang diduga sebagai benda asing sehingga menyebabkan 
perubahan pada permukaan sel ${ }^{1}$. Stres, ${ }^{8}$ genetik, makanan, obat-obatan, plak gigi, penyakit sistemik dan higiene mulut yang buruk diduga menjadi pemicu terjadinya OLP. ${ }^{9,10}$

Penyakit ini umum terjadi, yaitu mengenai sekitar $1-2 \%$ populasi ${ }^{3,4,5,7,11}$ dan lebih sering mengenai wanita dibandingkan pria ${ }^{1-5,8,11}$ dengan perbandingan 2:1.,4 OLP umumnya terjadi pada individu antara 30-60 tahun. ${ }^{1-3,5,7,8}$

Penyakit ini memiliki beberapa bentuk manifestasi klinis yang dapat mengakibatkan pasien merasa tidak nyaman dengan rongga mulutnya ${ }^{1,11}$. Beberapa bentuk manifestasi klinis dari OLP yaitu retikular, papula, bentuk plak, atropik, erosif dan bula., ${ }^{4,11}$ Lesi-lesi ini biasanya terjadi bilateral ${ }^{12}$ pada mukosa bukal, mukobukal fold, gingiva, ${ }^{1,7}$ lidah dan bibir. ${ }^{3}$ Tipe retikular merupakan bentuk umum dari OLP. ${ }^{1,3}$ Biasanya muncul dengan gambaran striae-striae keratotik putih (Wickham's striae ) dengan batas eritema ${ }^{1,5}$. Bentuk plak dari OLP mulai dari bentuk rata, halus hingga irregular. Biasanya ditemui pada lidah dan mukosa bukal. Tipe retikular dan plak biasanya tidak menimbulkan rasa sakit. Bentuk erosif merupakan bentuk umum yang kedua dari OLP, berupa gambaran area eritema dan ulserasi. ${ }^{1}$ Apabila terdapat pada gingiva, maka disebut deskuamatif gingivitis. ${ }^{1,3}$ Tipe ini biasanya menimbulkan rasa sakit dan ketidaknyamanan pada pasien. ${ }^{1,3,4,7}$ Bentuk atropik dari OLP biasanya difus, eritematus yang dikelilingi striae putih. Sedangkan bentuk bula dari OLP biasanya muncul pada mukosa bukal dan daerah lateral dari lidah. Bentuk bulla ini biasanya langsung pecah dan meninggalkan gambaran erosif., ${ }^{1,3}$

Sebenarnya tidak perlu perawatan pada OLP terutama tipe retikular dan plak., Perawatan hanya diberikan untuk mengurangi panjang dan keparahan dari gejala simtomatis, ${ }^{1}$ terutama pada lesi atropik dan ulseratif., ${ }^{2,3}$ Menurut beberapa literatur dikatakan bahwa perawatan OLP dapat berupa kortikosteroid, ${ }^{2,8}$ retinoid, ${ }^{2,4,8}$ cyclosporine $^{2,6}$ dan phototherapy., Sebagai tambahan, terdapat beberapa obat yang juga dipakai yaitu dapsone, griseofulvin, ${ }^{1}$ lysosomotropic amines, azathioprine ${ }^{2,6}$ dan mycophenolate mofetil yang digunakan baik sebagai pengobatan sendiri ataupun steroidsparing agents. ${ }^{8}$

Laporan kasus ini membahas suatu kasus OLP tipe retikular, erosif dan ulseratif pada pasien yang kemudian diketahui memiliki penyakit sistemik diabetes melitus yaitu peningkatan kadar gula darah yang terjadi sewaktu perawatan rongga mulutnya dilakukan sehingga mempengaruhi keparahan lesi serta penatalaksaannya.

\section{Laporan Kasus}

Pada tanggal 21 November 2007, seorang pasien wanita berusia 52 tahun, dirujuk dari poliklinik gigi salah satu rumah sakit swasta di Jakarta dengan working diagnosis lichen planus pada pipi dalam kanan dan kiri dan moniliasis pada lidah. Pasien telah diberi obat jamur nistatin untuk mengobati moniliasis pada lidah. Pasien dengan kondisi tersebut dirujuk untuk penatalaksanaan lichen planus di bagian Penyakit Mulut.

Dari anamnesis diperoleh informasi terdapat luka kemerahan pada pipi bagian dalam kanan dan kiri yang disertai rasa sakit pada saat makan sejak dua bulan yang lalu. Awalnya pasien mengatakan ada bercak putih yang menjadi warna merah pada pipi dan lidah. Pasien telah berobat ke dokter spesialis telinga hidung dan tenggorokan (THT) dan diberi obat salep yang mengandung ekstrak sanguin dan polidocanol. Setelah menggunakan obat salep tersebut, rasa sakit telah berkurang tetapi masih terdapat luka kemerahan pada pipi dalam pasien. Pasien tidak mengeluh adanya demam. Pasien juga pernah menderita tekanan darah tinggi tetapi sudah lama pasien tidak mengkonsumsi obat penurun tekanan darah dan hanya mengontrolnya dengan olahraga. Riwayat penyakit lain pasien adalah gastritis serta menopause sejak umur 45 tahun. Pasien menyangkal adanya riwayat penyakit diabetes melitus dan mengonsumsi obat-obatan lain. Riwayat gangguan psikologis diakui oleh pasien. Pasien sudah mendapatkan tindakan pembersihan karang gigi. Pasien masih dapat menyikat gigi dua kali sehari dengan 
menggunakan pasta gigi yang mengandung deterjen.

Keadaan umum pasien pada kunjungan pertama tampak baik. Pada pemeriksaan ekstra oral tidak terdapat kelainan hanya bibir bawah terlihat kering dan terdapat striae-striae putih, menyebar serta tidak sakit. Pada kondisi intra oral ditemukan kebersihan mulut baik, hanya terdapat debris makanan dan stain yang menyeluruh pada gigi geligi rahang atas dan bawah. Margin gingiva hiperemis, erosif dan terdapat striae putih di bagian posterior kanan dan kiri terutama regio 15, 16, 17, 18, 25, 26, 27, 28. Pada mukosa bukal kanan terdapat striae-striae putih berbentuk jala-jala, menyebar pada regio 45, 46, 47 dan 48 disertai daerah eritema, sedangkan pada mukosa bukal kiri terdapat lesi ulserasi dalam pada regio 26, diameter $3 \mathrm{~mm}$, disertai daerah erosif dan eritema serta rasa sakit. Sedangkan pada regio 35, 36 dan 37 pada mukosa bukal kiri juga terdapat striae-striae putih berbentuk jala-jala, menyebar rata dan tidak sakit. Pada mukosa labial bawah terdapat plak putih berdiameter 2 mm pada region 41 dan 42 tanpa disertai rasa sakit. Palatum durum, palatum mole dan dasar mulut tidak terdapat kelainan. Pada lidah terdapat plak putih, tidak dapat diangkat pada seluruh dorsum lidah serta terdapat striae-striae putih, menyebar pada posterior ventral lidah kanan dan kiri. Dari pemeriksaan gigi geligi terdapat gigi 26 dengan cusp lebih ke bukal, karies email pada gigi 28, 38 dan 48, karies dentin gigi 37 serta fraktur cusp distobukal pada gigi 47. ( gambar 1 )

Berdasarkan pemeriksaan subjektif dan objektif, diagnosis yang ditegakkan saat itu adalah dugaan adanya OLP ( tipe retikular, plak, erosif dan ulseratif ), deskuamatif gingivitis pada gingiva posterior atas kanan dan kiri, gigi 28, 37, 38 dan 48 iritasio pulpa serta gigi 47 iritasio pulpa e.c fraktur. Pada pasien diberikan oral health education ( OHE ) tentang penjelasan penyakit dan rencana perawatan serta anjuran untuk pemeriksaan darah lengkap, fungsi hati dan kadar glukosa darah. Pasien diinstruksikan untuk menyikat gigi secara perlahan dengan menggunakan pasta gigi tanpa mengandung deterjen, menyeka lidah, meneruskan penggunaan obat salep yang sudah ada pada ulserasi mukosa bukal kiri, pemberian kortikosteroid topikal dalam bentuk kumur, pelembab bibir, obat anti jamur dan multivitamin. Kortikosteroid topikal diberikan dengan anjuran melarutkan $10 \mathrm{mg}$ tablet prednison ke dalam air matang sebanyak $10 \mathrm{ml}$
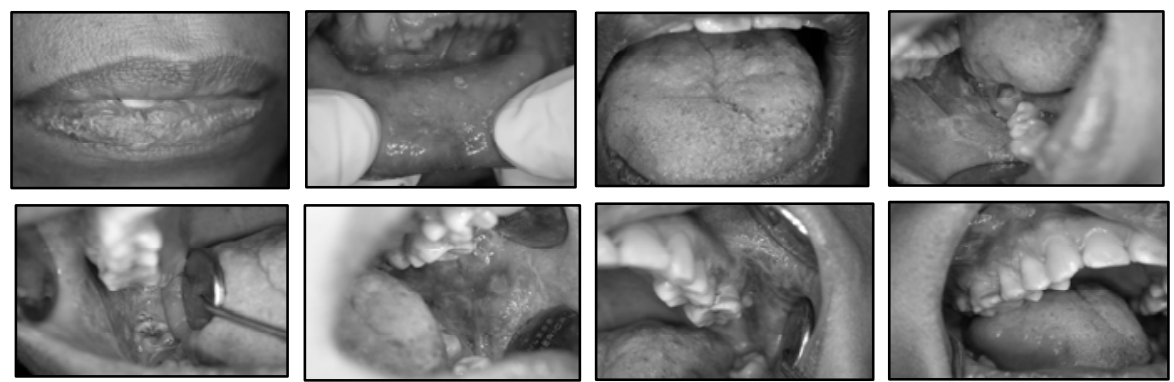

Gambar 1 (Kunjungan I)
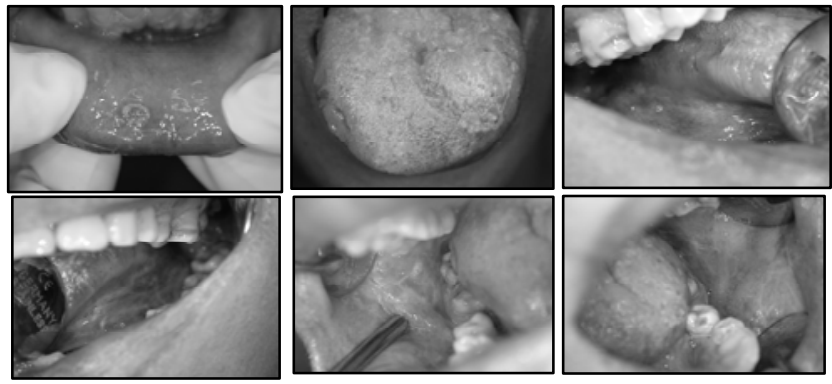

Gambar 2 ( Kunjungan V) 
yang dikumur dua kali sehari selama beberapa menit pada pagi dan malam hari.Dilakukan juga penghalusan cusp yang mengiritasi pada gigi 26 dan 47 serta direncanakan untuk penumpatan gigi geligi. Pasien kontrol seminggu kemudian dengan kondisi subjektif yang lebih baik. Rasa sakit pada pipi bagian dalam sudah berkurang hanya masih terdapat bercak putih dan merah, serta bibir masih terasa kering dan kaku. Pasien tidak membawa hasil pemeriksaan darah oleh karena belum sempat melakukan pemeriksaan. Pasien juga telah mengganti pasta gigi, menyeka rongga mulut serta memakai obatobatan sesuai anjuran. Pada pemeriksaan intra oral masih ditemukan striae-striae putih, daerah erosif dan eritema pada mukosa bukal kanan,
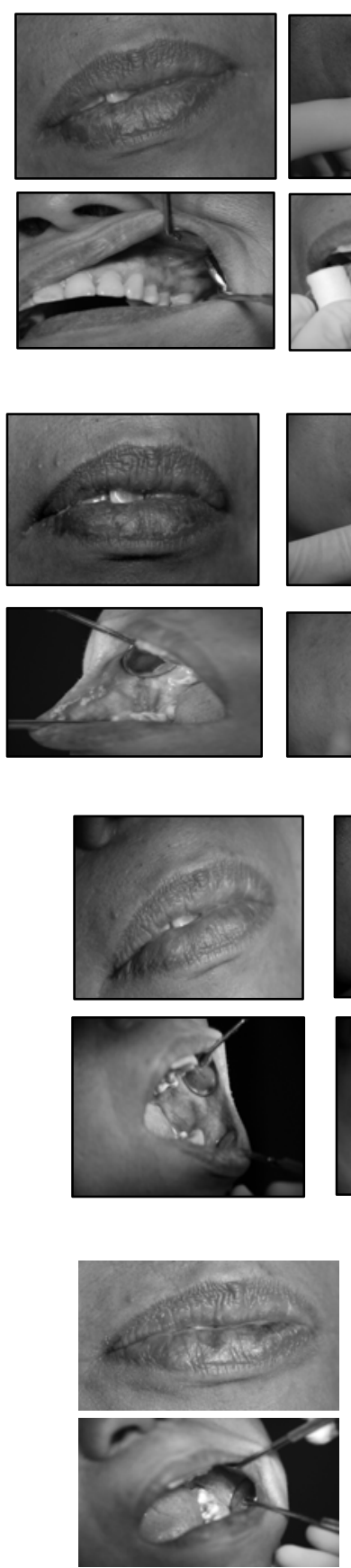
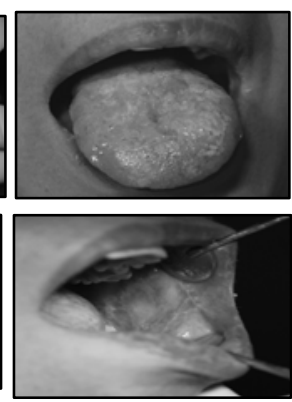

Gambar 3 ( Kunjungan VI )
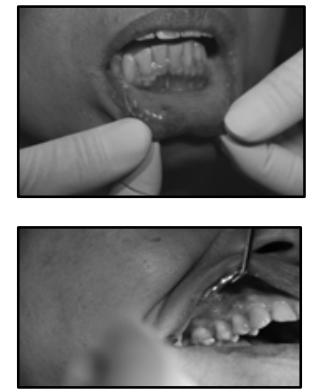

Gambar 4 ( Kunjungan VIII )
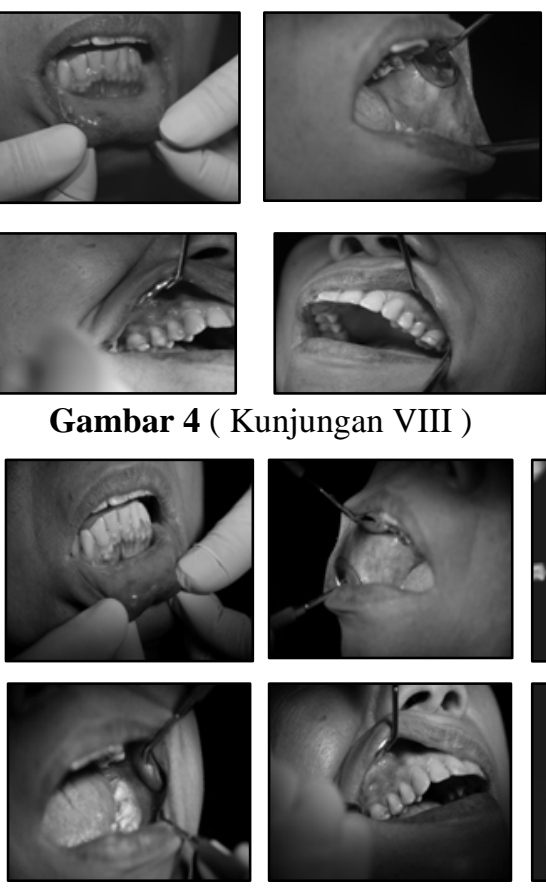

Gambar 5 ( Kunjungan X )

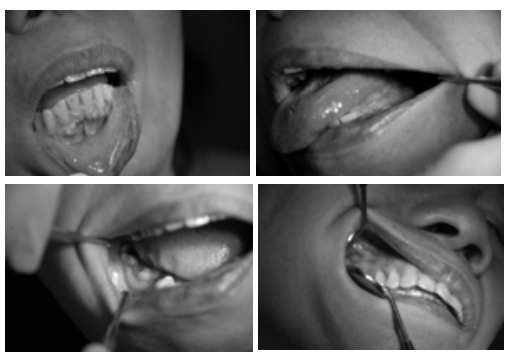

Gambar 6 ( Kunjungan XVI )
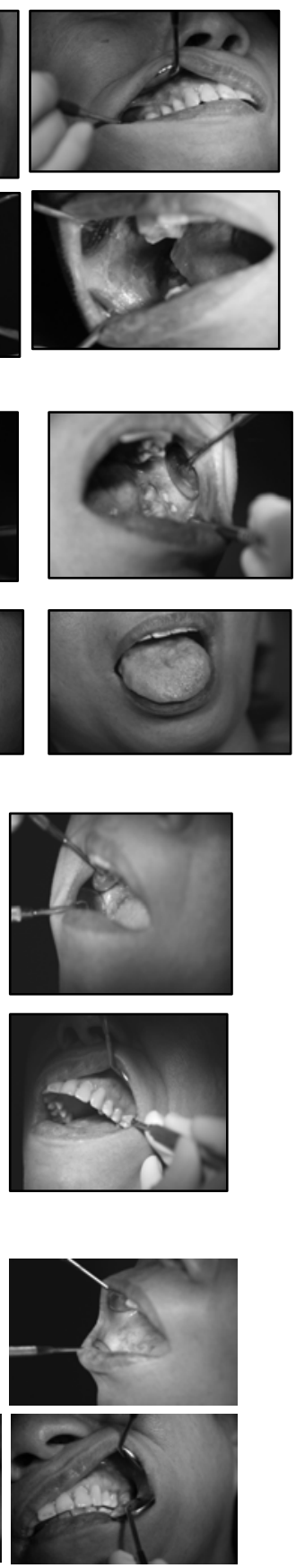
kiri, mukosa labial, gingiva atas kanan dan kiri serta ventral lidah bagian posterior, tetapi ulser pada regio gigi 26 sudah sembuh. Pada kunjungan kedua ini pemberian obat kortikosteroid kumur masih diteruskan dengan dosis yang sama, pemberian multivitamin serta obat oles kortikosteroid topikal yang mengandung triamcinolone acetonide 0,1\%. Obat oles digunakan pada daerah gingiva atas kanan dan kiri dengan mengaplikasikannya setiap selesai makan dan sebelum tidur serta tidak makan dan minum minimal 30 menit setelah menggunakan obat-obatan tersebut. Obat antijamur dan oles bibir masih tetap dilanjutkan. Pada pasien juga diinformasikan tentang kemungkinan penyebab penyakitnya serta anjuran untuk menghindari stres dan istirahat yang cukup serta menghindari makanan yang mengiritasi.

Pada kunjungan-kunjungan berikutnya terlihat adanya perbaikan lesi yaitu berkurangnya ukuran daerah eritema tetapi lesilesi yang berbentuk striae masih ditemui. Dari anamnesis diketahui bahwa pasien sudah dapat mengkonsumsi makanan dan buah-buahan dengan baik tetapi masih menghindari makanan yang mengiritasi. Pemberian obat kortikosteroid kumur telah diturunkan sesuai dengan perkembangan lesi dan secara bertahap hingga 5 mg per hari serta menggantikan pemakaian obat anti jamur dengan pemberian obat kumur yang mengandung klorheksidin glukonat 0,2\% (gambar 2).

Pada kunjungan ke-6, pasien mengeluh kembali rasa tidak nyaman pada rongga mulut dan bibir terasa kaku dan susah untuk membuka mulut karena adanya rasa sakit. Pada pemeriksaan intra oral terlihat lesi masih terdapat pada mukosa bukal kanan dan kiri, labial bawah, ventral lidah kiri posterior serta gingiva atas posterior kanan dan kiri. Pada bibir masih terdapat striae putih yang disertai eritema terutama pada bibir bawah. ( gambar 3 ) Pada kunjungan ini, dosis prednison dinaikkan menjadi $10 \mathrm{mg}$ per hari, pemberian obat oles berupa krim clobetasol proprionate 0,05\% dan meneruskan obat oles yang mengandung triamcinolone acetonide $0,1 \%$ serta berkumur dengan larutan klorheksidin glukonat. Pada bibir juga diberi obat oles racikan yang mengandung prednison. Terlihat adanya perbaikan lesi pada kunjungan-kunjungan berikutnya.

Pada tanggal 13 Maret 2008 ( 4 bulan dari kunjungan awal ) muncul plak-plak putih yang dapat diangkat dan meninggalkan daerah eritema hampir pada seluruh mukosa rongga mulut, yaitu pada mukosa bukal kanan dan kiri serta mukosa labial bawah. Pasien mengeluh mukosa rongga mulut terasa panas. Pasien kemudian dirujuk untuk pemeriksaan mikologi langsung dan biakan, dengan hasil terdapat koloni candida albicans. Pada pasien diberikan obat antijamur dan pemberian kortikosteroid kumur dua hari sekali (alternate day). ( gambar 4)

Pada tanggal 22 April 2008 dianjurkan kembali pada pasien untuk melakukan pemeriksaan darah lengkap, fungsi hati dan kadar glukosa darah. Berdasarkan hasil pemeriksaan darah diperoleh nilai dalam batas normal kecuali peningkatan laju endap darah 25 $\mathrm{mm} / \mathrm{jam}$, penurunan eosinofil $0 \%$, penurunan nilai monosit $1 \%$ dan peningkatan kadar glukosa darah sewaktu $220 \mathrm{mg} / \mathrm{dl}$. Dari hasil pemeriksaan tersebut, pasien dirujuk ke bagian penyakit dalam untuk evaluasi dan tatalaksana peningkatan kadar glukosa darahnya. Keluhan di rongga mulut sudah tidak dirasakan pasien, tetapi masih terdapat striae-striae putih tipis disertai eritema dan erosi pada regio 38 dan 48 pada mukosa bukal yang memang sulit dibersihkan dan diaplikasikan obat. Pada gingiva atas kanan dan kiri juga masih terdapat erosi disertai striae putih tipis terutama regio gigi 14 dan 25. Pada saat ini penggunaan obat kumur prednison dihentikan, sehingga pasien hanya memakai obat oles kortikosteroid (gambar 5).

Dari bagian penyakit dalam kembali dilakukan pemeriksaan kadar glukosa darah dengan hasil, kadar glukosa puasa $175 \mathrm{mg} / \mathrm{dl}$, kadar glukosa 2 jam pp 351 mg/dl serta kadar HbA1c 10,9. Pasien diberi obat glucodex gliclazide $80 \mathrm{mg}(1 \mathrm{x} 1)$ dan multivitamin. Kondisi rongga mulut terakhir terlihat semakin baik, hanya masih terdapat lesi erosi dan striae tipis pada daerah yang sulit dijangkau, yaitu 
mukosa bukal region 38 dan 48 yang bersentuhan dengan gigi tersebut. Pasien dianjurkan tetap memakai obat oles kortikosteroid, obat kumur yang mengandung klorheksidin glukonat, peningkatan higiene oral dan rencana pencabutan gigi 38 dan 48 apabila kondisi gula darah pasien sudah stabil ( gambar 6 ).

\section{Pembahasan}

Pada kasus ini, diagnosis yang ditegakkan pada awal kunjungan adalah oral lichen planus (OLP) yaitu berdasarkan pemeriksaan subjektif dan salah satu gambaran klinis lesi intra oral yang khas berupa striae-striae putih, berbentuk jala-jala (Wickham's Striae) dengan batas eritema yang terjadi bilateral pada mukosa bukal, ventral lidah dan gingiva. Diagnosis OLP dapat ditegakkan apabila gambaran klinisnya khas yaitu munculnya bentuk retikular yang klasik. ${ }^{1}$ Bentuk retikular dari OLP merupakan bentuk yang paling sering muncul, yaitu berupa lesi berwarna putih yang berbentuk seperti jalajala penghubung dan garis yang saling bertumpuk, menyebar dilatarbelakangi oleh daerah yang eritema dan biasanya jarang menimbulkan keluhan. ${ }^{3}$ Tindakan biopsi biasanya dilakukan apabila gambaran yang khas pada OLP tidak ada , terutama pada tipe erosif ${ }^{1}$ dan digunakan untuk memantau potensi keganasan dari OLP. ${ }^{3,8}$ Resiko berkembangnya OLP menjadi karsinoma sel skuamosa adalah sebanyak 10 kali lebih tinggi dari populasi yang sehat. Diagnosis banding dari OLP adalah leukoplakia, karsinoma sel skuamosa, discoid lupus eritematous, kandidiasis kronis, pemfigus vulgaris, benign mucous membrane pemphigoid, lichenoid reaction, erythema multiforme, hypersensitivity mucositis dan graft-versus-host disease. ${ }^{1}$

Yang menarik adalah berbedanya pengobatan terhadap pasien ini dengan pengobatan pada kasus OLP umum lainnya. Pada pasien, terdapat banyak faktor yang harus dipertimbangkan baik itu dari kondisi rongga mulut, penyakit sistemik yang dapat menghambat bahkan memperparah kondisi lesinya, pemilihan obat yang diberikan dan kepatuhan pasien terhadap instruksi perawatan.

Pada awal kunjungan, kondisi OLP diduga sebagai akibat dari kondisi stres yang sering dialami pasien. Menurut pasien, durasi dan keparahan lesi berkaitan dengan kondisi dan riwayat stres. Beberapa penelitian menyatakan bahwa faktor psikologis merupakan penyebab terjadinya lichen planus baik itu di kulit dan mukosa rongga mulut. ${ }^{13}$ Rojo-Monero et al (1998) juga menyatakan bahwa pasien dengan OLP tipe erosif memiliki skor depresi yang lebih tinggi dibandingkan dengan pasien yang tidak memiliki lesi erosif. Ditambah dengan adanya rasa ketidaknyamanan di dalam mulut, maka pasien akan lebih memikirkan penyakitnya yaitu rasa ketakutan kemungkinan terjadi keganasan, penyakit menular dan ketidakpercayaan diri pasien. Intervensi psikologis ini dapat menimbulkan efek meningkatnya kadar kortisol pada pasien, yang mendukung keterkaitan OLP dengan stres. ${ }^{3}$ Kondisi stres disini merubah kerja sistem saraf otonom baik simpatik maupun parasimpatik sehingga mengakibatkan perubahan kontrol hipotalamik dan respon endokrin yang diatur oleh glandula pituitari. Aktivitas otonom dan adanya peningkatan dari hormon termasuk hormon yang dihasilkan oleh hypothalamopituitary-adrenal axis merupakan faktor yang berperan dalam mekanisme sistem imun, yaitu produksi sitokin yang berperan dalam mengontrol proses inflamasi dan penyembuhan. ${ }^{12}$ Dalam hal ini penting untuk memberikan informasi kepada pasien tentang penyakit dan perawatannya serta edukasi kepada pasien tentang perilaku dan hal-hal yang dapat mendukung keberhasilan perawatan. ${ }^{14}$

Setelah terapi 6 bulan, pada pasien terlihat adanya peningkatan kadar glukosa darah. Hal ini baru diketahui pada pertengahan perawatan karena pada awalnya telah disarankan pemeriksaan glukosa darah tetapi tidak segera dapat dilakukan oleh pasien. Salah satu pemicu terjadinya OLP adalah penyakit sistemik. Hubungan antara OLP dan diabetes telah luas diteliti, tetapi masih tetap menimbulkan perdebatan. Beberapa literatur mengatakan adanya kaitan antara terjadinya OLP dengan 
diabetes ${ }^{15}$ karena tingginya insiden OLP pada pasien tersebut. Sejak tahun 1963, David Grinspan menjelaskan adanya hubungan antara OLP dengan diabetes melitus, ${ }^{15}$ tetapi hubungan ini tidak selalu terjadi dan biasanya disebabkan karena pemakaian obat anti diabetes atau obatobatan lainnya. $^{10}$ Diabetes melitus terutama yang tipe ke-2 sering kali tidak terdiagnosa sampai beberapa tahun karena biasanya pada fase awal penyakit ini tidak menimbulkan gejala yang mengganggu pasien. ${ }^{10}$ Hingga laporan ini dibuat, kondisi diabetes melitus pasien masih tidak stabil. Beberapa penelitian mengatakan tingginya prevalensi lesi OLP tipe erosif pada penderita diabetes bisa disebabkan karena kondisi diabetes ini dapat memperparah lesi OLP. ${ }^{10}$ Hal ini juga dapat terjadi karena kondisi stres pasien yang memperparah kondisi kadar glukosa darahnya. Dibutuhkan pemberian informasi, edukasi dan motivasi kepada pasien agar mengikuti instruksi terutama dalam mengontrol stres sehingga penyebab terjadinya OLP di rongga mulut dapat dicegah.

Berdasarkan gambaran klinis terdapat bentuk OLP selain retikular yaitu lesi erosif atau atrofi dan ulserasi yang menimbulkan rasa tidak nyaman dan perih, terdapat pada mukosa bukal kiri karena adanya iritasi dari gigi 26. Faktor yang diduga dapat memperparah kondisi lesi adalah trauma mekanis dari prosedur kedokteran gigi, panas dan iritasi dari produk tembakau serta cusp gigi yang tajam, buruknya restorasi tambalan, gigi tiruan yang tidak baik ${ }^{6}$ ataupun kebiasaan buruk seperti menggigit bibir dan pipi. ${ }^{3}$ Selain menggunakan obat-obatan, perawatan OLP juga dilakukan dengan mengeliminasi faktor pencetus dan peningkatan higiene oral. ${ }^{8}$ Kondisi yang disebabkan oleh trauma ini disebut dengan Koebner phenomenon yang menerangkan mengapa daerah erosif OLP sering pada daerah yang terkena trauma seperti mukosa bukal dan lateral lidah. Ketika faktorfaktor tersebut dihilangkan, dapat mengurangi atau bahkan menyembuhkan lesi erosif di rongga mulut. ${ }^{3}$

Faktor lain yang menjadi tantangan dalam pengobatan OLP pada pasien ini adalah pemilihan obat yang digunakan. Perawatan OLP pada pasien ini terutama dilakukan pada lesi yang berbentuk erosif dan ulseratif yang terdapat pada bagian posterior dari mukosa bukal kanan dan kiri, gingiva, lidah dan bibir bawah. Pada awalnya diberikan obat berupa kortikosteroid kumur yaitu prednison $10 \mathrm{mg}$ dua kali sehari pagi dan malam. Kortikosteroid berperan dalam perawatan lesi vesikulo-erosif. ${ }^{16}$ Perawatan yang sering digunakan pada OLP adalah kortikosteroid $^{1,11}$ topikal atau sistemik ${ }^{4}$ untuk mengontrol respon imun pasien ${ }^{1}$. Topikal kortikosteroid lebih sering digunakan pada OLP, karena lebih efektif $^{6}$ yaitu dengan berkontaknya obat tersebut dengan mukosa, ${ }^{3}$ baik dalam bentuk salep, spray ataupun kumur. ${ }^{14}$ Bentuk salep dan spray biasanya diberikan pada lesi setempat dan dapat dijangkau sedangkan bentuk kumur biasanya digunakan pada lesi yang meluas. ${ }^{8,14}$ Dalam hal ini, semakin banyak kontak obat dengan lesi, maka semakin efektif penggunaannya. Apabila keluhan berkurang, maka dilakukan penurunan dosis sampai kadar minimum yang dapat mengontrol keluhan. Jika tidak ada perbaikan hingga 2 minggu, sebaiknya dipertimbangkan penggunaan kortikosteroid yang lebih kuat atau penggunaan secara sistemik untuk mengobati keluhan. $^{14}$ Kortikosteroid sistemik biasanya digunakan pada pasien dengan OLP yang tidak respon terhadap kortikosteroid topikal ${ }^{1}$, terutama pada lesi erosif yang parah. ${ }^{6}$

Pada perawatan OLP, kortikosteroid biasanya digunakan untuk mendapatkan efek antiinflamasi dan imunosupresif. ${ }^{4,16-19}$ Kortikosteroid bekerja berikatan dengan reseptor sitoplasmik untuk merubah regulasi sintesis protein. Salah satu protein pengatur yaitu lipocortin, merupakan bagian dari protein superfamili tambahan yang menghambat fosfolipase A2 dan metabolisme dari asam arakidonik pada leukotrienes, prostaglandin dan thromboxanes yang terlibat dalam proses inflamasi. Glukokortikoid juga meningkatkan sintesis reseptor beta sehingga mengurangi permeabilitas mikrovaskular, mengurangi produksi sitokin, mast sel dan eosinofil. Mekanisme antiinflamasi melibatkan reseptor glukokortikoid, gen responsif glukokortikoid dan pelepasan molekul antiinflamasi seperti lipocortin-1, IL-10, IL-1 dan NF-kB. 
Kortikosteroid juga merekam encoding gen dan menghambat nuclear factor kappa B subtype a dan mengurangi jumlah NF-kB pada nucleus sehingga sekresi sitokin proinflamatori berkurang. ${ }^{16,19}$ Sedangkan efek imunosupresif dari kortikosteroid didapat terutama dari mensupresi proliferasi sel $\mathrm{T}$ melalui hambatan pelepasan IL-1 dari monosit. ${ }^{16}$

Setelah beberapa kunjungan, lesi OLP pasien mengalami perbaikan, hanya tersisa pada daerah yang susah dijangkau atau mungkin tidak terkena dengan cara berkumur, yaitu daerah mukosa bukal regio 38 dan 48 dimana mukosa menempel pada gigi geligi tersebut, regio gingiva atas kanan dan kiri serta pada bibir. Kemudian pasien diberi obat salep kortikosteroid berupa krim clobetasol propionate $0,05 \%$ yang dikombinasikan dengan pasta triamcinolone acetonide $0,1 \%$. Alasan penggunaan kedua obat ini secara bersamaan yaitu obat dalam bentuk krim akan sulit melekat lama di mukosa rongga mulut karena sifatnya yang mudah larut dalam saliva, untuk itu diperlukan bahan pasta adhesif untuk membantu perlekatannya. Penggunaan kortikosteroid memerlukan pertimbangan yang luas, diantaranya kondisi lesi baik keparahan atau luasnya lesi dan riwayat penyakit umum. ${ }^{16}$ Clobetasol propionate merupakan kortikosteroid tipe superpoten ${ }^{16}$ yang dilaporkan sering digunakan secara topikal pada OLP., Pada lesi erosif di bibir bawah diberikan obat kortikosteroid topikal racikan yang mengandung prednison. Setelah dua minggu terlihat perbaikan lesi baik di bibir maupun pada gingiva yang ditandai dengan berkurangnya ukuran lesi dan rasa sakit yang dialami pasien.

Menurut literatur, dibandingkan dengan penggunaan sistemik, pemberian kortikosteroid secara topikal memiliki efek samping yang lebih sedikit, seperti kandidiasis, penipisan mukosa rongga mulut dan ketidaknyamanan sewaktu pengaplikasiannya. Efek samping yang mungkin terjadi karena pemakaian kortikosteroid sistemik adalah insomnia, diare, gangguan pada system saraf pusat seperti psychotic, retensi sodium dan cairan, lelah, rentan terhadap infeksi, hipertensi, hiperglikemia dan supresi adrenal, ${ }^{1}$ sehingga riwayat medis merupakan faktor penting dalam pertimbangan penggunaannya. ${ }^{16}$ Pada pasien, setelah 4 bulan pemakaian obat kumur prednison, obat kortikosteroid krim dan pasta terdapat plak putih yang dapat diangkat serta meninggalkan daerah yang eritema pada mukosa bukal kanan dan kiri serta mukosa labial bawah. Pasien juga mengeluhkan rasa panas. Kemudian dilakukan pemeriksaan mikologi langsung dan biakan dan hasilnya terdapat kandidiasis dengan koloni candida albicans dalam biakan. Hal ini mungkin dikaitkan dengan pemakaian kortikosteroid topikal jangka panjang, adanya keluhan xerostomia yang dirasakan pasien karena kondisi menopause dan stres. Kandidiasis oral dapat terjadi hingga $25-55 \%$ pada penggunaan kortikosteroid topikal. $^{20}$ Spesies candida merupakan penyebab infeksi jamur yang tersering di dalam rongga mulut. Adanya faktor lokal dan sistemik pada pasien menyebabkan transisi candida dari yang komensal menjadi patogen. Muzyka dan Glick menyatakan bahwa kortikosteroid menurunkan resistensi terhadap candida yaitu dengan menekan respon inflamasi nonspesifik dan cell-mediated immunity. ${ }^{21}$ Lundstrom et al melaporkan setelah perawatan terhadap anti jamur akan meningkatkan keberhasilan perawatan OLP sebanyak 90\% dan transformasi dari OLP dari yang tipe erosif menjadi tipe yang retikular, ${ }^{6}$ yang biasanya tidak menimbulkan rasa sakit. ${ }^{21}$

Terjadinya peningkatan kadar glukosa darah pada perawatan memberi dugaan apakah karena pemakaian kortikosteroid kumur jangka panjang atau pada awalnya pasien sudah memiliki kadar glukosa darah yang tinggi. Peningkatan kadar gula darah juga diduga akibat pemakaian obat kortikosteroid kumur jangka panjang. Berbagai faktor dapat meningkatkan efek samping, yaitu penggunaan dosis tinggi kortikosteroid topikal pada konsentrasi yang tinggi, overdosis dan terdapatnya pembuluh darah yang terbuka pada permukaan ulserasi, luasnya daerah erosi dan atropik serta kuat tekanan kumur pada permukaan ulserasi. $^{20}$ Terapi dengan kortikosteroid dan obat immunomodulasi lainnya berpotensial menimbulkan efek 
samping. ${ }^{15}$ Salah satu keuntungan penggunaan kortikosteroid topikal adalah efek samping yang lebih sedikit dibandingkan penggunaan secara sistemik. Walaupun absorbsi sistemik dari penggunaan topikal steroid rendah, tetapi hal ini seharusnya tidak diabaikan. Perawatan topikal kortikosteroid dapat menghasilkan peningkatan kadar glukosa darah secara sementara sebagai akibat dari glukoneogenesis dan menurunnya sensitifitas jaringan terhadap insulin. Steroid mengganggu toleransi glukosa dengan menurunkan pengrusakan glukosa pada jaringan perifer dan meningkatkan pengeluaran glukosa pada hati sehingga mengakibatkan resistensi dari insulin. ${ }^{22}$

Oleh karena itu, perlu kerjasama dengan bagian penyakit dalam karena penggunaan kortikosteroid bekerja melawan aksi insulin sehingga menimbulkan hiperglikemia. ${ }^{15}$ Kemungkinan efek samping yang terjadi pada penggunaan topikal kortikosteroid harus terus dimonitor terutama apabila penggunaan kortikosteroid potensi tinggi yang digunakan lebih dari tiga kali per hari yaitu dengan kontrol setiap dua minggu dan setiap bulan apabila penyakitnya sudah dapat dikontrol dan penurunan frekuensi pemakaian harus dilakukan. Pada setiap kontrol sebaiknya dilakukan pengukuran kadar gula darah, tekanan darah dan berat badan. ${ }^{20}$

Kondisi diabetes melitus tentu mempengaruhi perawatan OLP selanjutnya pada pasien. Pada lesi yang masih ada, pemakaian kortikosteroid sistemik merupakan kontraindikasi hingga kondisi diabetes melitus pasien teratasi. Pemilihan obat dan perencanaan terapi selanjutnya pada pasien menjadi tantangan selama kondisi glukosa darah pasien masih belum stabil. Selain penggunaan kortikosteroid, ada beberapa pilihan obat yang dapat dipakai dalam terapi OLP. Topikal retinoid efektif dalam perawatan OLP, tetapi memiliki efek samping berupa rasa terbakar di rongga mulut. ${ }^{2,8}$ Penggunaan retinoid secara sistemik memiliki banyak efek samping yaitu peningkatan kadar transaminase, hiperlipidemia, cheilitis, alopecia dan dystropic nail formation. ${ }^{8}$ Hersle juga mengatakan bahwa adanya keluhan sakit kepala dan terdapatnya reaksi pada kulit apabila menggunakan retinoid sistemik. $^{2}$ Tacrolimus dan pimecrolimus dikatakan lebih efektif penggunaannya dibandingkan cyclosporin topikal tetapi harus hati-hati karena penggunaannya dapat meningkatkan keganasan. ${ }^{8}$ Harpenau mengatakan bahwa penggunaan cyclosporin dalam dosis rendah tidak memiliki efek samping. Sedangkan menurut penelitian Eisen dikatakan bahwa penggunaannya dalam dosis yang tinggi dapat menimbulkan keluhan rasa terbakar pada rongga mulut. Pemberian photosensitizer psoralen memiiki efek samping rasa mual dan efek neurologis ringan pada pasien. ${ }^{2}$

Pemilihan obat non steroid imunomodulator dapat dipertimbangkan dalam perawatan mukosa rongga mulut dengan kondisi diabetes yang tidak stabil. ${ }^{15}$ Tetapi hal ini harus terus dipertimbangkan sesuai dengan kondisi umum dan respon efek sampingnya terhadap pasien sehingga harus ada kerjasama dan kepatuhan pasien sehingga dapat dicapai keberhasilan terapi dengan efek samping yang minimal.

Terapi yang diberikan sampai laporan ini dibuat adalah kortikosteroid krim dan pasta, hal ini karena lesi yang tersisa terdapat pada daerah yang terlokalisasi. Rencana pencabutan gigi 38 dan 48 yang mengiritasi daerah mukosa bukal kanan menjadi tertunda sampai kadar glukosa darah pasien memungkinkan. Dibutuhkan kerjasama yang baik dengan bagian Ilmu Penyakit Dalam dan terus memonitor kadar glukosa darahnya serta kunjungan berkala di bagian Penyakit Mulut untuk memonitor kondisi rongga mulutnya.

\section{Kesimpulan}

OLP merupakan penyakit pada mukosa rongga mulut yang sering terjadi dengan faktor penyebab yang belum diketahui secara pasti. OLP merupakan salah satu penyakit yang sering terjadi pada penderita diabetes melitus sehingga perlu dilakukan pemeriksaan kadar gula darah pada pasien ini. Untuk diperoleh perawatan OLP dengan latar belakang diabetes melitus yang komprehensif membutuhkan kooperatif 
pasien dalam mengendalikan stres, mengikuti instruksi pengobatan, kontrol terhadap kadar glukosa darah dan pemilihan obat yang tepat. Penggunaan obat kortikosteroid sistemik pada pasien OLP dengan diabetes melitus harus hatihati. Pilihan utama pada kasus ini adalah kortikosteroid topikal. Penggunaan obat non steroid imunomodulator lain dapat dipertimbangkan sesuai dengan kondisi pasien.

\section{Daftar Acuan}

1. Edwards PC, Kelsch R. Oral Lichen Planus: Clinical Presentation and Management. J Can Dent Assoc 2002; 68(8): 494-9.

2. Chan ESY, Thornhill M, Zakrzewska JJM. Interventions for treating oral lichen planus (Review). The Cochrane Library 2008; 4: 1-23.

3. Eisen D, Carozzo M, Sebastian JVB, Thongprasom K. Oral lichen planus: clinical features and management. Oral Diseases 2005; 11: 338-49.

4. Buajeeb W, Kraivaphan P, Pobrurksa C. Efficacy of topical retinoic acid compared with topical fluocinolone acetonide in the treatment of oral lichen planus. Oral Surg Oral Med Oral Pathol Oral Radiol Endod 1997; 83: 21-5.

5. Sugerman PB, Savage NW. Oral lichen planus: causes, diagnosis and management. Australian Dental Journal 2002; 47(4): 290-7.

6. Lodi $\mathrm{G}$, et al. Current controversies in oral lichen planus: Report of an international consensus meeting. Part 2. Clinical management and malignant transformation. Oral Surg Oral Med Oral Pathol Oral Radiol Endod 2005; 100: 164-78.

7. Sugerman PB, et al. The Pathogenesis of Oral Lichen Planus. Crit Rev Oral Biol Med 2002; 13(4): 350-65.

8. Al-Hashimi I et al. Oral lichen planus and oral lichenoid lesions: diagnostic and therapeutic considerations. Oral Surg Oral Med Oral Pathol Oral Radiol Endod 2007; 103 (suppl 1): S25S31.

9. Lukac J et al. Serum autoantibodies to Desmogleins 1 and 3 in patients with Oral Lichen Planus. Croat Med J 2006; 47: 53-8.
10. Romero MA, et al. Prevalence of diabetes mellitus amongst oral lichen planus patients. Clinical and pathological characteristics. Medicina Oral 2002: 7: 121-9.

11. Eisen D. The Therapy of Oral Lichen Planus. Crit Rev Oral Biol Med 1993; 4(2): 141-58.

12. Chiappelli F, Cajulis OS. Psychobiologic views on stress-related oral ulcers. Quintessence Int 2004; 35: 223-7.

13. McCartan BE. Psychological factors associated with oral lichen planus. J Oral Pathol Med 1995; 24: 273-5.

14. Huber MA. Oral lichen planus. Quintessence Int 2004; 35: 731-52.

15. Vernillo AT. Dental considerations for the treatment of patients with diabetes mellitus. $J$ Am Dent Assoc 2003; 134: 24S-33S.

16. Gonzales-Moles MA, Scully C. Vesiculoerosive Oral Mucosal Disease- Management with Topical Corticosteroid: (1) Fundamental Principles and Spesific Agents Avaliable. J Dent Res 2005; 84 (4): 294-301.

17. Lester RS, Knowles SR, Shesr NH. The risk of systemic corticosteroid use. Clin Dermatol 1998; 16 (2): 277-88.

18. Savage NW, McCullough MJ. Topical corticosteroids in dental practice. Aus Dent $J$ 2005; 50 (suppl 2): S40-S44.

19. Scully C, Cawson RA. Medical problems in dentistry. $5^{\text {th }}$ ed. Churchill Livingstone. 2005: 88-9.

20. Gonzales-Moles MA, Scully C. Vesiculoerosive Oral Mucosal Disease- Management with Topical Corticosteroid: (2) Protocols, Monitoring of Effects and Adverse Reactions, and the Future. J Dent Res 2005; 84 (4): 302- 8.

21. Jainkittivong A, Kuvatanasuchati J, Pipattanagovit P, Sinheng W. Candida in oral lichen planus patients undergoing topical steroid therapy. Oral Surg Oral Med Oral Pathol Oral Radiol Endod 2007; 104: 61-6.

22. Kymionis GD, Panagiotoglou T, Tsilimbaris. The Effect of Intense, Short-Term Topical Dexamethasone Disodium Phosphate Eyedrops on Blood Glucose Level in Diabetic Patients. Opthalmologica 2007; 221: 426-9. 